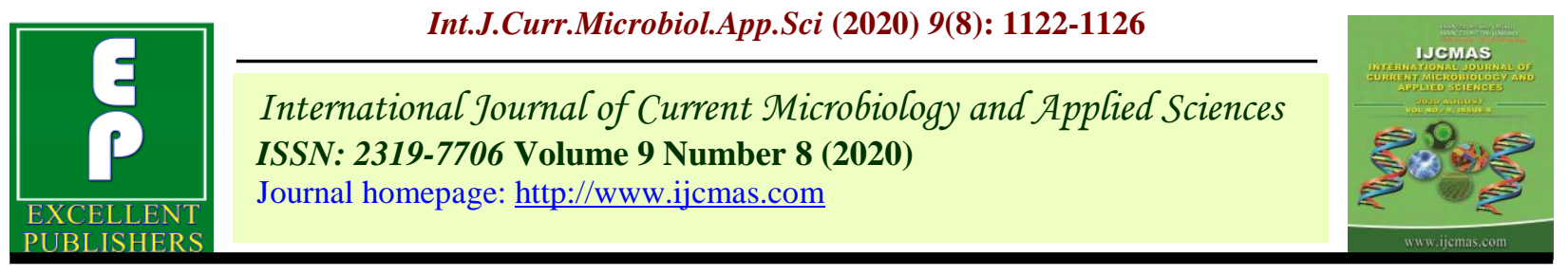

Original Research Article

https://doi.org/10.20546/ijcmas.2020.908.123

\title{
Screening of Tomato Cultivars/varieties against Fusarium oxysporum f. sp. Lycopersici causing Wilt of Tomato
}

\author{
S. B. Sanap, K. L. Jaiswal", V. S. Mete, S. B. Sanap and V. G. Mulekar \\ Department of Plant Pathology, College of Agriculture, Latur, India \\ *Corresponding author
}

\section{A B S T R A C T}

\begin{tabular}{l} 
Ke y w o r d s \\
Tomato, Wilt, \\
$\begin{array}{l}\text { Fusarium } \\
\text { oxysporum f. sp. } \\
\text { lycopersici, } \\
\text { Screening and poly } \\
\text { bag culture }\end{array}$ \\
\hline Article Info \\
$\begin{array}{l}\text { Accepted: } \\
\text { 10 July } 2020 \\
\text { Available Online: } \\
10 \text { August } 2020\end{array}$ \\
\hline
\end{tabular}

Tomato (Lycopersicon esculentum Miller) cultivars/varieties were evaluated to identify the source of resistance against wilt caused by Fusarium oxysporum $\mathrm{f}$. sp. lycopersici. Therefore, efforts were made to evaluate the different varieties/cultivars of tomato for screening against Fusarium oxysporum f. sp. lycopersici in vivo (poly bag culture) condition. Among seven varieties tested for screening in vivo, two varieties i.e., US 440 and Master F1 found tolerant with mean disease incidence in the range of $7.14 \%$ to $8.92 \%$ respectively. Jigar variety was found moderately susceptible with mean disease incidence of 18.57\%. Two varieties S-22, and Pusa hybrid-4 were found susceptible with mean disease incidence of $33.73 \%$ and $23.80 \%$. Whereas, PKM-1 $(55.95 \%)$ and Pusa rubi $(62.69 \%)$ were found highly susceptible to wilt disease.

\section{Introduction}

Tomato (Lycopersicon esculentum M.) is one of the most important vegetable crops cultivated for its fleshy fruit and also considered as important commercial and dietary vegetable crop. India is the second largest producer and consumer of tomato in the world after China. In India, tomato was grown in about 0.797 million ha with an annual production of 207.08 million tonnes and productivity of 25.98 tonnes per ha during 2017 (FAOSTAT, 2019). The major tomato growing states in India are Madhya Pradesh, Orissa, Karnataka, West Bengal, Chhattisgarh, Andhra Pradesh, Telangana,
Gujarat, Bihar, Maharashtra and Tamil Nadu which accounted for 91 per cent of the total production of the country (Anonymous, 2017). Among various factors responsible for low production and productivity of tomato, the diseases caused by biotic agents are major one. The crop is vulnerable to number of diseases such as Bacterial wilt (Ralstonia solanacearum), Fusarium wilt (Fusarium oxysporum), Early blight (Alternaria solani), Late blight (Phytophthora infestans), Damping off (Pythium and Rhizoctonia) and Yellow leaf curl. Among all these diseases, Fusarium wilt caused by Fusarium oxysporum f. sp. lycopersici is the most devastating fungal disease. Joshi et al., (2013) 
reported that the soil borne fungus $F$. oxysporum is the causal agent of vascular wilt, the disease that affects a large variety of economically important crops worldwide. Considering these issues, present study was planned and conducted with the aim to evaluate the screening of different varieties/cultivars in vivo condition against $F$. oxysporum f. sp. lycopersici causing wilt in tomato.

\section{Materials and Methods}

Screening of available varieties of tomato against the disease

Screening of available tomato cultivars were conducted in polythene bag containing $F$. oxysporum f. sp. lycopersici inoculum developed by the mass multiplication (sick soil) in non-replicated manner.

\section{Disease rating Scale}

\begin{tabular}{|c|c|c|}
\hline Scale & Description & Disease reaction \\
\hline 0 & No wilting & Resistant \\
\hline 1 & $1 \%$ or less plant wilting & Moderately resistant \\
\hline 3 & 1 to $10 \%$ plant wilting & Tolarent \\
\hline 5 & 11 to $20 \%$ plant wilting & Moderately susceptible \\
\hline 7 & 21 to $50 \%$ plant wilting & Susceptible \\
\hline 9 & $51 \%$ and more plant wilting & Highly Susceptible \\
\hline
\end{tabular}

Observation on disease severity of the varieties were recorded as per rating scale given by Mayee and Datar, (1986) and the varieties were categorized as resistant (R), moderately resistant (M), tolerant (T), moderately susceptible (MS), susceptible (S) and highly susceptible (HS) as described by Nene et al., (1981).

Based on numerical rating observed, per cent disease intensity was calculated by applying the formula (Mckinney, 1923) as given below.

$$
\begin{aligned}
& \text { Summation of numerical rating } \\
& \text { Per cent disease Intensity = } \\
& \text { No. of plants observed } \mathrm{x} \text { maximum rating }
\end{aligned}
$$

\section{Results and Discussion}

Screening of tomato cultivars/varieties against Fusarium oxysporum f. sp. lycopersici. (poly bag culture).

In order to find out the sources of resistance in tomato for Fusarium wilt, seven tomato varieties were collected from Vegetable
Research Scheme, V.N.M.K.V, Parbhani and screened under artificial inoculation condition in poly bags at College of Agriculture Latur during Rabi 2018-

Results (Table 1 \& PLATE I) revealed that, under poly bag culture, all the 7 tomato entries exhibited different reactions against Fusarium oxysporum f. sp. lycopersici. However, two varieties found tolerant with mean disease incidence in the range of $7.14 \%$ (US 440) to $8.92 \%$ (Master F1). One variety was found moderately susceptible with mean disease incidence of $18.57 \%$ (Jigar). Two varieties S-22, and Pusa hybrid- 4 were found susceptible with mean disease incidence of $23.80 \%$ and $33.73 \%$. Whereas, PKM-1 (55.95\%), and Pusa rubi (62.69\%), were found highly susceptible to wilt.

Categorization of tomato cultivars/varieties against Fusarium oxyspor um f. $\mathbf{s p .}$ lycopersici (poly bag culture).

A total of 7 varieties of tomato were collected from Vegetable Research Scheme, V.N.M.K.V, Parbhani and screened under 
artificial inoculation condition in poly bags at college of agriculture, Latur during Rabi 2018-19 against Fusarium oxysporum f. sp. lycopersici. The observations on per cent wilt incidence were recorded after starting of fruiting of the crop and test entries of tomato were graded and categorized as resistant (no incidence), moderately resistant $(<1 \%)$, tolerant (1-10\%), moderately susceptible (11$20 \%)$, susceptible (21-50\%) and highly susceptible $(<50 \%)$ and are presented in (Table 2 \& PLATE I).
The data revealed that the two cultivars found tolerant (US 440 and Master F1). One variety was recorded as moderately susceptible (Jigar). Two varieties S-22, and Pusa hybrid 4 were recorded as susceptible whereas, PKM-1 and Pusa Rubi recorded as highly susceptible reaction under artificial inoculation in pot culture which needs to be confirmed under sick pot condition rigorously for two or more years before utilizing it in breeding program.

Table.1 Reaction of tomato cultivars/ varieties to wilt (poly bag culture)

\begin{tabular}{|c|c|c|c|}
\hline Sr. No & Tomato lines & $\begin{array}{c}\text { Wilt incidence } \\
(\mathbf{\%})\end{array}$ & Disease reaction \\
\hline 1 & Pusa rubi & 62.69 & Highly Susceptible \\
\hline 2 & PKM-1 & 55.95 & Highly Susceptible \\
\hline 3 & S-22 & 33.73 & Susceptible \\
\hline 4 & Pusa hybrid 4 & 23.80 & Susceptible \\
\hline 5 & Jigar & 18.57 & Moderately Susceptible \\
\hline 6 & US 440 & 7.14 & Tolerant \\
\hline 7 & Master F1 & 8.92 & Tolerant \\
\hline
\end{tabular}

Table.2 Categorization of tomato cultivars/ varieties according to wilt incidence against $F$. oxysporum f. sp. lycopersici (poly bag culture)

\begin{tabular}{|c|c|c|c|c|}
\hline Category & Reaction & & Avg. wilt & Varieties/ \\
\hline & & & incidence $(\%)$ & Cultivars \\
\hline 0 & Resistant & & No wilting & 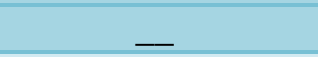 \\
\hline 1 & Moderately & Resistant & $<1$ & 4 \\
\hline \multirow[t]{2}{*}{3} & Tolerant & & 1 to 10 & US 440, Master \\
\hline & & & & $\mathrm{F} 1$ \\
\hline \multirow[t]{2}{*}{5} & Moderately & & 11 to 20 & Jigar \\
\hline & Susceptible & & & \\
\hline \multirow[t]{2}{*}{7} & Susceptible & & 21 to 50 & S-22, Pusa hybrid - \\
\hline & & & & 4 \\
\hline 9 & Highly & Susceptible & $>51$ & Pusa rubi, PKM-1 \\
\hline
\end{tabular}


Plate.1 Tomato cultivars showing reaction to $F$. oxysporum f. sp. lycopersici inoculation

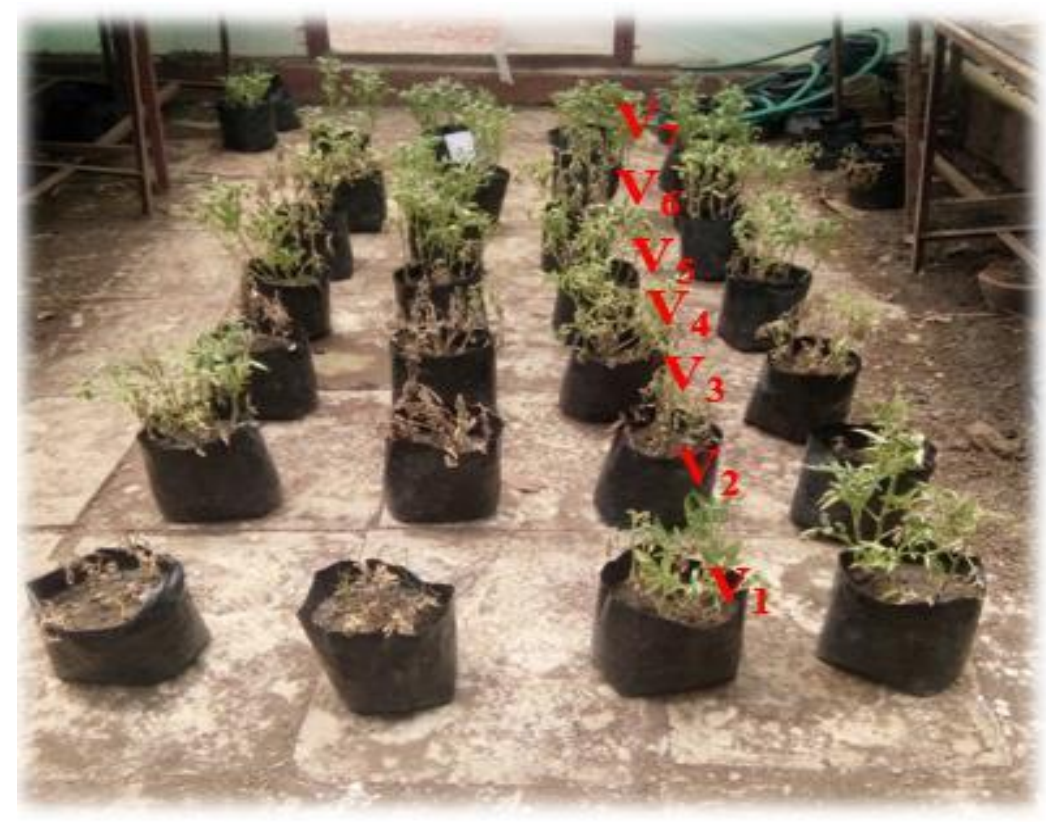

\begin{tabular}{|c|l|c|l|}
\hline Sr. No & Variety Name & Sr. No. & Variety Name \\
\hline $\mathrm{V}_{1}$ & Pusa rubi & $\mathrm{V}_{5}$ & Tigar \\
\hline $\mathrm{V}_{2}$ & PKM-1 & $\mathrm{V}_{6}$ & US 440 \\
\hline $\mathrm{V}_{3}$ & S-22 & $\mathrm{V}_{7}$ & Master F1 \\
\hline $\mathrm{V}_{4}$ & Pusa hybrid 4 & & \\
\hline
\end{tabular}

Similar results were earlier reported by Serife et al., (2018); Onyekachukwu et al., (2017); Akram et al., (2014); Chebri (2012); and Ashwag (2003). They revealed that the results showed clear variation among the tested differential tomato cultivars. According to the percentage of infection on differential cultivars against the isolate of Fusarium oxysporum f. sp. lycopersici. It was revealed that the $\%$ of dead and stunted plants were 58.25 and 41.5, respectively for cv. Marmande verte which gave susceptible reaction whereas Motelle and Marporum were resistant to tested isolate.

\section{References}

Akram, W., A. Tehmina, and A. Aqeel. 2014: Basal susceptibility of tomato varieties against different isolates of Fusarium oxysporum f. sp. lycopersici. Int. J. Agric. Biol. 16:171-176.

Anonymous, 2017: Horticultural Statistics at a Glance 2017: Published by Horticulture Statistics Division, Department of Agriculture, Co operation and Farmers Welfare, Ministry of Agriculture \& Farmers Welfare, Government of India: 1-481.

Ashwag, M. I. 2003: Investigations of Fusarium oxysporum f. sp. lycopersici, The Causal agent of tomato wilt (Lycopersicon esculentum Mill). M.Sc.(Agri) Thesis, Agriculture University, Khartoum. Pp 42-45.

FAOSTAT, 2019: World area harvested, yield and production quantity of tomatoes. http://www.fao.org/faostat /en/\#data/QC.

Joshi, M., R, Srivastava, A. K. Sharma, and 
A. Prakash, 2013: Isolation and characterization of Fusarium oxysporum, a wilt causing fungus, for its pathogenic and nonpathogenic nature in tomato. McKeneey 1923: A new system of grading plant diseases. $J$. Agric. Res. 26: 195218.

Nene, Y. L., Haware, M. P. and Reddy, M. V. 1981: Chickpea diseases: resistancescreening techniques. Information Bulletin No. 10. International Crops Research Institute for the Semi-Arid Tropics. Patancheru, A. P., India. ICRISAT. pp. 1-10.
Onyekachukwu, O., Akaeze., O. Adefoyeke. and M. Aduramigba. 2017: Fusarium wilt disease of tomato: screening for resistance and in vitro evaluation of botanicals for control; The Nigeria Case. J. Microbiol. Biotech. Food. Sci. 7(1):32-36.

Serife, E. A., C. Oguzcan. and S. Ozdinc. 2018: Screening some tomato seedlings for Fusarium oxysporum f. sp. lycopersici (Fol). Int. Envi. Tre. 2(1): 44-52.

\section{How to cite this article:}

Sanap, S. B., K. L. Jaiswal, V. S. Mete, S. B. Sanap and Mulekar, V. G. 2020. Screening of Tomato Cultivars/varieties against Fusarium oxysporum f. sp. Lycopersici causing Wilt of Tomato. Int.J.Curr.Microbiol.App.Sci. 9(08): 1122-1126. doi: https://doi.org/10.20546/ijcmas.2020.908.123 